\title{
Antibacterial activity of Nepalese wild mushrooms against Staphylococcus aureus and Propionibacterium acnes
}

\author{
Sonam Tamrakar ${ }^{1} \cdot$ Marina Nishida $^{1} \cdot$ Yhiya Amen $^{1} \cdot$ Hai Bang Tran ${ }^{1} \cdot$ \\ Hiroto Suhara $^{2} \cdot$ Katsuya Fukami $^{3}$ - Gopal Prasad Parajuli ${ }^{4} \cdot$ Kuniyoshi Shimizu $^{1}$
}

Received: 1 February 2017/ Accepted: 14 April 2017/Published online: 5 June 2017

(C) The Japan Wood Research Society 2017

\begin{abstract}
The present study aims to reveal the antibacterial potential of the wild mushrooms of Nepal. Despite the recognition of the medicinal potential of the natural resources in this country, a systematic study on the bioactivities of the wild mushrooms is still lacking. Therefore, in an attempt to fill this gap, ethanol extracts of 90 Nepalese wild mushroom samples were tested for antibacterial activity against Staphylococcus aureus and Propionibacterium acnes. Staphylococcus aureus was comparatively more susceptible with Inonotus clemensiae exhibiting the least minimum bactericidal concentration (MBC) of $100 \mu \mathrm{g} / \mathrm{mL}$. The major compound in $I$. clemensiae was identified to be hispidin using high resolution liquid chromatography-electron spray ionization mass spectrometry (LC-ESI-MS) and nuclear magnetic resonance (NMR) analyses. Furthermore, the minimum inhibitory concentration (MIC) and MBC values of hispidin were determined to be 25 and $100 \mu \mathrm{g} / \mathrm{mL}$ for $S$. aureus and $P$. acnes, respectively. These findings show that the Nepalese wild mushrooms have the potential to be a
\end{abstract}

Electronic supplementary material The online version of this article (doi:10.1007/s10086-017-1636-1) contains supplementary material, which is available to authorized users.

Kuniyoshi Shimizu

shimizu@agr.kyushu-u.ac.jp

1 Faculty of Agriculture, Kyushu University, Fukuoka, Japan

2 Miyazaki Prefectural Wood Utilization Research Center, Miyazaki, Japan

3 Material Management Center, Kyushu University, Fukuoka, Japan

4 Plant Pathology Division, Nepal Agriculture Research Council, Lalitpur, Nepal novel addition to the functional ingredients industry due to their strong antibacterial potential.

Keywords Wild mushrooms · Nepal · Antibacterial activity · Inonotus clemensiae · Hispidin

\section{Introduction}

Staphylococcus aureus and Propionibacterium acnes are bacterial species known to have adverse effects on skin health [1]. Colonization of these bacteria on the skin causes the onset and pathogenesis of skin conditions like acne vulgaris, boils, and impetigo [2]. Increasing bacterial resistance and prevalence of side effects from currently available treatments [3], underscores the need for alternative treatment sources. Inhibition of skin problem causing bacteria serves as an important functional property in skin cosmetics too [4].

The dietary and medicinal uses of mushrooms can be traced back to ancient times. Mushrooms have proven to be a vast reservoir of bioactive compounds, exhibiting biological activities such as antioxidant, antibacterial, antiviral, anticancer, anti-obesity, and anti-inflammatory activities [5]. Over the years, mushrooms have transcended from being traditional remedies to bioactive ingredients in medicines and functional foods [6, 7]. The bioactive properties of mushrooms have found important implications in skin health and cosmetics too [8].

Several mushroom species are known to have antibacterial effect on $S$. aureus. However, the antibacterial effect on $P$. acnes is much less studied. Lentinus edodes, Ganoderma lucidum and Phellinus linteus are few examples of mushrooms that have antibacterial effect against $S$. aureus [9]. Ganoderma pfeifferi is known to have activity against 
$P$. acnes and other skin problem causing bacteria [5]. The antimicrobial activity of mushrooms have been attributed to several different compounds, ranging from low molecular weight compounds such as phenolic acids, terpenes, steroids, quinolones to high molecular weight compounds such as peptides and proteins [9]. Desbois et al. [10] reported the antibacterial activity of polyunsaturated fatty acids against both $S$. aureus and $P$. acnes.

Nepal, a country located between India and China, is gifted with a rich biodiversity due to its unique landscape and climatic conditions. Over a 1000 species of mushrooms have been reported from this country [11]. Despite the diversity and huge potential, the use of mushrooms in Nepal is limited to the consumption, and traditional medicinal uses [12] of a few species. The exploration of the therapeutic potential and the cultivation techniques of the indigenous wild mushrooms could add a new dimension to the Nepalese mushroom market and functional food industry. However, apart from some studies on the antioxidant activities [13, 14], other biological activities of Nepalese mushrooms remain largely unstudied. Therefore, in an attempt to fill this gap, the current research explores the antibacterial property of the ethanol extracts of 90 Nepalese wild mushrooms samples against $S$. aureus and $P$. acnes. In-depth chemical analysis of selected species elucidates the nature of the compounds responsible for the antibacterial activity. Therefore, the present study shall elucidate the antibacterial potential and chemical components of different wild mushroom samples of Nepal, for its prospective use as medicinal agents and cosmeceuticals.

\section{Materials and methods}

\section{Mushroom samples}

Mushrooms which developed basidiomata were collected from forests in Nepal. Ninety different samples were investigated in this study. The botanical origin, location, habitat, and identification of the samples have been described in previously published reports [13, 14].

\section{Reagents}

Difco $^{\text {TM }}$ Nutrient broth and agar were purchased from Becton, Dickinson \& Company, France. Gifu anaerobic medium (GAM) broth and agar were purchased from Nissui Pharmaceutical Co. Ltd., Japan. Anaero Pack system was procured from Mitsubishi Gas Chemical Co. Inc., Japan. Benzalkonium chloride was obtained from MP Biomedicals, LLP, France. Sorbic acid, protocatechualdehyde, homovanillic acid, vanillin, protocatechuic acid and the organic solvents used for chemical characterization were procured from Wako Pure Chemical Industries, Japan. Hispidin was obtained from Amadis Chemicals, China. All the chemicals and solvents used were of analytical grade with purity of at least $97 \%$.

\section{Extract preparation}

The mushroom samples were first air dried and then dried in an oven at $35{ }^{\circ} \mathrm{C}$ for $10 \mathrm{~h}$ followed by $45^{\circ} \mathrm{C}$ for $1 \mathrm{~h}$. The dried samples were ground to a fine powder, and extracted in ethanol. The extractions were performed by shake flask method in an orbital shaker at $200 \mathrm{rpm}$, for $24 \mathrm{~h}$ at room temperature. The extracts were then filtered and rotary evaporated to dryness at $45^{\circ} \mathrm{C}$, under reduced pressure.

\section{Antibacterial assay}

The antibacterial assay for $S$. aureus was based on the method described by Tanaka et al. [15]. A single colony of S. aureus (NBRC 1273) was inoculated to $5 \mathrm{~mL}$ of nutrient broth, and incubated at $37{ }^{\circ} \mathrm{C}$ at $1160 \mathrm{rpm}$ for $18 \mathrm{~h}$. The bacterial concentration was adjusted to $1 \times 10^{5}$ colony forming units $(\mathrm{CFU}) / \mathrm{mL}$. The mushroom extracts were dissolved in dimethyl sulfoxide (DMSO) at the maximum dissolved concentration (final concentration 100-400 $\mu \mathrm{g}$ / $\mathrm{mL}$ ). Sorbic acid (final concentration $400 \mu \mathrm{g} / \mathrm{mL}$ ) and DMSO were used as positive and negative controls, respectively. In a 96-well plate, $133.5 \mu \mathrm{L}$ of the nutrient broth, $15 \mu \mathrm{L}$ of the bacterial suspension, and $1.5 \mu \mathrm{L}$ of the sample suspension/controls were added to each well $(n=3)$. Blank wells with $148.5 \mu \mathrm{L}$ of nutrient broth and $1.5 \mu \mathrm{L}$ of sample/controls were also included. The plate was incubated at $37^{\circ} \mathrm{C}, 1160 \mathrm{rpm}$ for $18 \mathrm{~h}$. Bacterial growth was measured using a micro-plate reader (BiotekELX800, BioTek) set at $630 \mathrm{~nm}$. The antibacterial activity was calculated as the inhibition percentage with reference to the negative control, DMSO. The samples exhibiting antibacterial activity greater than or equal to the positive control were selected for the determination of Minimum Inhibitory Concentration (MIC) and the Minimum Bactericidal Concentration (MBC). The concentration of the samples was serially decreased, starting from the maximum dissolved concentration, to detect the concentration which inhibited visual growth of the bacteria, i.e., MIC. After obtaining the MIC, the concentration of the samples were serially increased, starting from the MIC, to obtain the minimum concentration in which there was no colony formation upon plating in the nutrient agar plates, i.e., MBC.

In case of $P$. acnes, the method was slightly modified. The stock solution of $P$. acnes (NBRC 107605) was retrieved from the cold storage $\left(-80^{\circ} \mathrm{C}\right)$ and thawed. A $50 \mu \mathrm{L}$ of portion was added to $5 \mathrm{~mL}$ of GAM broth. It was 
then incubated under anaerobic condition using the Anaero Pack jar system at $37{ }^{\circ} \mathrm{C}$ for $24 \mathrm{~h}$. The concentration of the bacterial suspension was adjusted to $1 \times 10^{5} \mathrm{CFU} / \mathrm{mL}$. Benzalkonium chloride (final concentration $200 \mu \mathrm{g} / \mathrm{mL}$ ) was used as positive control. The assay was performed in a 96-well plate following the same method as described for $S$. aureus. The plates were then incubated in anaerobic condition at $37^{\circ} \mathrm{C}$ for $30 \mathrm{~h}$. The absorbance was measured at $630 \mathrm{~nm}$. The MIC and MBC values were determined for samples with the inhibition percentage greater than or equal to the positive control.

\section{Statistical analysis}

All the assays were conducted at least 3 times, and the results are expressed as mean \pm standard deviation. Significant differences between sample groups were analyzed by Kruskal-Wallis test followed by Dunn-Bonferroni test. The statistical analyses were performed using SPSS statistics Version 23. The $p$ value less than 0.05 were considered statistically significant.

\section{Liquid chromatography-mass spectrometry (LC-MS) analysis}

High resolution LC-MS analysis was done to elucidate the compounds present in the samples with detectable MIC and MBC. LC-MS-IT-TOF, Shimadzu, Tokyo was fitted with an ODS-3 column $(150 \mathrm{~mm} \times 1.5 \mathrm{~mm}$ i.d., $5-\mu \mathrm{m}$ particle size). The solvent system comprised water with $0.1 \%$ formic acid as solvent $\mathrm{A}$ and acetonitrile with $0.1 \%$ formic acid as solvent B. The analysis was carried out at room temperature with a flow rate of $0.2 \mathrm{~mL} / \mathrm{min}$. The gradient flow of the mobile phase was set as: 0-10 $\mathrm{min}, 5-30 \% \mathrm{~B}$; 10-15 min, 30-40\% B; 15-30 min, 40\% B; 30-60 min, 40-70\% B; 60-70 min, 70-100\% B; 70-80 min, 100\% B; 80-85 $\mathrm{min}, 100-5 \% \mathrm{~B}$; $85-95 \mathrm{~min}, 5 \% \mathrm{~B}$. The LC chromatograms were recorded at the wavelengths of 280 and $254 \mathrm{~nm}$.

For MS, electron spray ionization (ESI) source was used in positive and negative ionization mode with $\mathrm{m} / \mathrm{z}$ values of 100-1000 for MS and 50-700 for MS/MS. A probe voltage of $\pm 4.5 \mathrm{kV}$, nebulizer gas flow of $1.5 \mathrm{~L} / \mathrm{min}$, curved desolvation line (CDL) temperature of $200{ }^{\circ} \mathrm{C}$, and heat block temperature of $200{ }^{\circ} \mathrm{C}$ were used. The peaks obtained were partially identified on the basis of retention time, $\mathrm{m} / \mathrm{z}$ values, and comparison with standard compounds.

\section{Nuclear magnetic resonance (NMR) analysis}

The structure of some of the compounds in the bioactive samples was confirmed by NMR analysis. Bruker DRX 600
NMR spectrometer (Bruker Daltonics Inc., MA, USA), was used to obtain the proton $\left({ }^{1} \mathrm{H}\right)$ and carbon-13 $\left({ }^{13} \mathrm{C}\right) \mathrm{NMR}$ spectra. Tetramethylsilane (TMS) was used as an internal standard for chemical shifts, and the chemical shifts $(\delta)$ were expressed in ppm with reference to the TMS resonance.

\section{Results}

\section{Percentage inhibition of $S$. aureus and $P$. acnes}

The ethanol extracts of 90 mushroom samples were tested for their activity against $S$. aureus and $P$. acnes. The inhibition percentage of the extracts, against both bacterial species is listed in Table 1. The samples were grouped into four groups on the basis of their taxonomic order as Hymenochaetales, Polyporales, Agaricales and Others. Since the majority of the sample fell into the first three orders, the few remaining samples were grouped together as "Others". The antibacterial activity was measured using the absorbance obtained at $630 \mathrm{~nm}$, and calculated as the percentage inhibition of the bacterial growth compared to the negative control (DMSO). Therefore, DMSO showed no $(0 \%)$ inhibition of bacterial growth and the positive controls showed a complete $(100 \%)$ inhibition.

Overall, S. aureus was more susceptible than P. acnes towards the antibacterial activity of the extracts. For $S$. aureus, significant differences were seen between the inhibition percentage for the groups Hymenochaetales and Polyporales. Hymenochaetales emerged as the strongest group, with 10 out of 20 samples showing more than $80 \%$ inhibition of $S$. aureus. A closer look within the group revealed that Inonotus andersonii, Inonotus clemensiae, Inonotus cuticularis, Inonotus sp. 2, and Cyclomyces setiporus 3 exhibited the highest inhibitory effect. However, interesting contrasts were seen in the samples belonging to the same genera such as Inonotus sp. 1, 3 and 5, which did not have any inhibitory effect on $S$. aureus. Polyporales showed a medium to low inhibitory effect on $S$. aureus, with the highest inhibitory effect reaching $73 \%$ for Laetiporus montanus. Almost half $(48.7 \%)$ of the samples within the group did not show any inhibition on the bacterial growth. Samples belonging to Ganoderma sp. showed very low to undetectable inhibition of $S$. aureus. Varying reports can be found for the antibacterial activity of the ethanol extracts of Ganoderma sp. against $S$. aureus. Quereshi et al. [16] reported a much lower inhibitory effect of the ethanol extract of G. lucidum compared to methanol and acetone extracts. The inhibitory activity of the Agaricales group also showed some variation. Only 3 samples (Mucidula mucida, Gymnopus sp., and Pleurotus ostreatus) out of 18 samples showed inhibition percentage greater 
Table 1 Percentage inhibition exhibited by the ethanol extracts of 90 wild mushroom samples on Staphylococcus aureus and Propionibacterium acnes

\begin{tabular}{|c|c|c|}
\hline $\begin{array}{l}\text { Order } \\
\text { Scientific name }\end{array}$ & S. aureus & P. acnes \\
\hline Hymenochaetales & $\mathrm{a}$ & a \\
\hline Inonotus andersonii & $102.0 \pm 0.7$ & $94.3 \pm 4.6$ \\
\hline Inonotus clemensiae & $100.3 \pm 0.1$ & $107.2 \pm 8.4$ \\
\hline Inonotus cuticularis & $98.8 \pm 1.3$ & $83.2 \pm 3.3$ \\
\hline Inonotus sp. 1 & nd & $31.7 \pm 3.2$ \\
\hline Inonotus sp. 2 & $102.0 \pm 7.9$ & $28.4 \pm 4.2$ \\
\hline Inonotus sp. 3 & nd & $19.2 \pm 9.4$ \\
\hline Inonotus sp. 4 & $92.2 \pm 12.0$ & $27.2 \pm 5.2$ \\
\hline Inonotus sp. 5 & nd & $42.4 \pm 7.6$ \\
\hline Phellinus gilvus & $25.8 \pm 1.8$ & $53.7 \pm 7.5$ \\
\hline Phellinus conchatus 1 & $9.8 \pm 1.7$ & $26.9 \pm 7.5$ \\
\hline Phellinus conchatus 2 & $7.9 \pm 2.8$ & $38.9 \pm 1.3$ \\
\hline Phellinus sp. 1 & $82.8 \pm 10.2$ & $60.1 \pm 7.6$ \\
\hline Phellinus sp. 2 & $22.0 \pm 9.3$ & nd \\
\hline Phellinus adamantinus & $83.3 \pm 1.7$ & $25.4 \pm 3.8$ \\
\hline Cyclomyces setiporus 1 & $93.7 \pm 12.6$ & $73.1 \pm 10.2$ \\
\hline Cyclomyces setiporus 2 & $28.1 \pm 4.3$ & $34.8 \pm 5.3$ \\
\hline Cyclomyces setiporus 3 & $103.9 \pm 0.1$ & $54.1 \pm 4.2$ \\
\hline Cyclomyces setiporus 4 & $86.3 \pm 3.6$ & nd \\
\hline Cyclomyces setiporus 5 & $59.5 \pm 8.4$ & nd \\
\hline Oxyporus sp. & nd & nd \\
\hline Polyporales & $\mathrm{b}$ & $\mathrm{b}$ \\
\hline Ganoderma australe 1 & nd & $11.5 \pm 9.7$ \\
\hline Ganoderma australe 2 & nd & nd \\
\hline Ganoderma australe 3 & nd & $19.3 \pm 7.1$ \\
\hline Ganoderma australe 4 & nd & nd \\
\hline Ganoderma lingzhi 1 & $51.8 \pm 10.5$ & nd \\
\hline Ganoderma lingzhi 2 & nd & $48.3 \pm 9.8$ \\
\hline Ganoderma lingzhi 3 & nd & $6.4 \pm 5.5$ \\
\hline Ganoderma endochroum & nd & $88.0 \pm 3.4$ \\
\hline Ganoderma multipileum & $18.4 \pm 5.3$ & nd \\
\hline Ganoderma carnosum ${ }^{*}$ & nd & $5.1 \pm 1.9$ \\
\hline Ganoderma sp. 1 & $38.6 \pm 14.1$ & $14.2 \pm 11.8$ \\
\hline Ganoderma sp. 2 & $16.2 \pm 9.8$ & $18.8 \pm 5.7$ \\
\hline Amauroderma calcigenum & $12.6 \pm 2.6$ & $1.7 \pm 2.4$ \\
\hline Trichaptum biforme & nd & $3.3 \pm 1.4$ \\
\hline Trichaptum abietinum & $25.0 \pm 4.2$ & nd \\
\hline Trametes versicolor 1 & $1.6 \pm 2.1$ & nd \\
\hline Trametes versicolor 2 & $3.5 \pm 2.6$ & $16.1 \pm 2.1$ \\
\hline Trametes versicolor 3 & $13.0 \pm 1.3$ & $35.6 \pm 1.7$ \\
\hline Trametes versicolor 4 & nd & nd \\
\hline Trametes versicolor 5 & nd & nd \\
\hline Microporus xanthopus 1 & nd & $5.09 \pm 9.7$ \\
\hline Microporus xanthopus 2 & $15.4 \pm 1.1$ & nd \\
\hline Polyporus arcularius & $19.3 \pm 4.0$ & $58.7 \pm 6.1$ \\
\hline Postia stiptica & nd & $109.0 \pm 1.0$ \\
\hline Phlebia tremellosa 1 & nd & nd \\
\hline Phlebia tremellosa 2 & $3.3 \pm 0.1$ & $57.4 \pm 5.1$ \\
\hline Lenzites betulina & nd & $3.4 \pm 3.5$ \\
\hline Rigidoporus sp. & nd & nd \\
\hline
\end{tabular}

Table 1 continued

\begin{tabular}{lll}
\hline Order & S. aureus & P. acnes \\
Scientific name & & \\
\hline
\end{tabular}

\begin{tabular}{|c|c|c|}
\hline Laetiporus versisporus 1 & $11.8 \pm 2.0$ & $8.0 \pm 5.1$ \\
\hline Laetiporus versisporus 2 & $67.2 \pm 1.9$ & nd \\
\hline Laetiporus montanus & $73.0 \pm 12.8$ & nd \\
\hline Mycorrhaphium sp.** & nd & nd \\
\hline Grifola frondosa & $67.2 \pm 15.4$ & nd \\
\hline Lentinus sp.** & $49.7 \pm 1.7$ & nd \\
\hline Bjerkandera adusta & $71.9 \pm 4.7$ & nd \\
\hline Antrodiella zonata 1 & nd & $32.2 \pm 7.7$ \\
\hline Antrodiella zonata 2 & $10.9 \pm 4.9$ & nd \\
\hline Fomes fomentarius & nd & nd \\
\hline Abortiporus biennis & $35.2 \pm 5.6$ & $54.3 \pm 3.4$ \\
\hline Agaricales & $\mathrm{ab}$ & $\mathrm{ab}$ \\
\hline Lentinula edodes 1 & nd & nd \\
\hline Lentinula edodes 2 & $21.3 \pm 8.3$ & $2.1 \pm 4.2$ \\
\hline Pleurotus ostreatus $1^{*}$ & $7.4 \pm 0.7$ & $12.4 \pm 2.0$ \\
\hline Pleurotus ostreatus $2^{*}$ & $84.7 \pm 14.3$ & $16.3 \pm 4.2$ \\
\hline Pleurotus ostreatus $3^{*}$ & $28.2 \pm 5.9$ & $13.6 \pm 5.8$ \\
\hline Pleurotus ostreatus 4 & $11.5 \pm 0.8$ & $22.0 \pm 10.4$ \\
\hline Pholiota nameko 1 & $44.6 \pm 8.6$ & nd \\
\hline Pholiota nameko 2 & $10.2 \pm 0.5$ & $11.4 \pm 1.8$ \\
\hline Marasmius mavium & $24.3 \pm 6.05$ & $89.4 \pm 1.2$ \\
\hline Marasmius sp. & $3.1 \pm 0.5$ & nd \\
\hline Panellus edulis & $18.6 \pm 8.3$ & nd \\
\hline Panellus sp. & nd & $16.4 \pm 0.2$ \\
\hline Inocybe sp. 1 & nd & $23.9 \pm 6.4$ \\
\hline Inocybe sp. 2 & nd & $24.8 \pm 1.2$ \\
\hline Collybia peronata & nd & $44.5 \pm 1.8$ \\
\hline Tricholoma caligatum & nd & $26.6 \pm 0.9$ \\
\hline Mucidula mucida* & $113.1 \pm 1.8$ & $75.7 \pm 2.9$ \\
\hline Gymnopus sp. & $113.7 \pm 1.2$ & nd \\
\hline Others & $\mathrm{ab}$ & $\mathrm{ab}$ \\
\hline Heterobasidion linzhiense 1 & nd & $40.4 \pm 6.3$ \\
\hline Heterobasidion linzhiense 2 & nd & $59.2 \pm 0.6$ \\
\hline Lactarius hatsutake & nd & $15.7 \pm 4.0$ \\
\hline Lactarius sp.** & $36.3 \pm 7.3$ & nd \\
\hline Russula brevipes & $28.8 \pm 1.3$ & nd \\
\hline Engleromyces goetzii & nd & $4.6 \pm 3.6$ \\
\hline Neolentinus lepideus & nd & nd \\
\hline Xylobolus princeps 1 & $76.5 \pm 7.6$ & $15.6 \pm 3.9$ \\
\hline Xylobolus princeps 2 & $105.7 \pm 11.2$ & $27.9 \pm 5.7$ \\
\hline Xylobolus princeps 3 & $100.1 \pm 8.7$ & $9.4 \pm 0.9$ \\
\hline Xylobolus princeps 4 & $96.1 \pm 1.7$ & nd \\
\hline Pseudomerulius curtisii & $102.1 \pm 0.9$ & $105.6 \pm 1.3$ \\
\hline Cantharellus ferruginascens & $132.9 \pm 2.0$ & nd \\
\hline
\end{tabular}

S. aureus is Staphylococcus aureus and P. acnes is Propionibacterium acnes. The values are expressed as "average \pm standard deviation", and $n=3$. nd means that there was no detectable inhibition of bacterial growth. Difference in letters in each column means that there is a statistical difference between groups at a significance level of $p<0.05$. The names of the mushrooms marked with double asterisk were tested at $100 \mu \mathrm{g} / \mathrm{mL}$, and those marked with asterisk were tested at $200 \mu \mathrm{g} / \mathrm{mL}$, and the remaining samples were tested at $400 \mu \mathrm{g} / \mathrm{mL}$ 
than $80 \%$. The Others group contained a mixture of low, medium and very high antibacterial samples. Xylobolus princeps (2-4), Pseudomerulius curtisii, and Cantharellus ferruginascens showed the strongest inhibitory effects of more than $90 \%$. Bala et al. [17] also found a strong antibacterial activity of the ethanol and water extracts of Cantharellus sp. against $S$. aureus.

Similar to $S$. aureus, $P$. acnes also showed a significant difference between groups for Hymenochaetales and Polyporales. Although Hymenochaetales prevailed as the strongest group; relatively fewer sample showed high inhibition percentage. Only, 3 samples (I. andersonii, I. clemensiae, and I. cuticularis) out of 20 samples showed inhibition percentage above $80 \%$. For Polyporales, almost half of the samples (48.7\%) within the group did not have any inhibitory effect on the bacterial growth. However, complete inhibition of bacterial growth was seen for Postia stiptica; and Ganoderma endochroum showed $88 \%$ inhibition of bacterial growth. Agaricales was limited to an undetectable to medium inhibitory effect with only one of the samples, Maramius mavium, showing inhibition percentage above $80 \%$. In the Others group, the only prominent sample that showed complete inhibition of the bacterial growth was Pseudomerulius curtisii.

\section{MIC and MBC}

The MIC and MBC were determined for extracts showing inhibition percentage greater or equivalent to the positive control. The MIC and MBC of 11 samples for S. aureus and 4 samples for $P$. acnes, and their respective positive controls are shown in Table 2. Around $40 \%$ of the samples tested belonged to the Hymenochaetaceae family of the Hymenochaetales group. The MBC could not be detected for 6 out of 12 samples tested for $S$. aureus, whereas for P. acnes all 4 samples had detectable MBC values. I. clemensiae extract required the least concentration of $100 \mu \mathrm{g} / \mathrm{mL}$ to achieve the MIC and MBC for S. aureus; and in the case of P. acnes, both I. clemensiae and P. stiptica had the least MIC and MBC of 100 and $200 \mu \mathrm{g} / \mathrm{mL}$, respectively. Although reports could not be found for I. clemensiae, Glamočlija et al. [18] reported the MIC and MBC values of ethanol extracts from Inonotus obliquus from Russia as 300 and $1500 \mu \mathrm{g} / \mathrm{mL}$, respectively, for S. aureus; where MIC was estimated as the lowest concentration of extract that showed no visible growth, and was not able to reduce 2-( $p$-iodophenyl)-3-( $p$ nitrophenyl)-5- phenyl tetrazolium chloride (INT), whereas the MBC was determined as the lowest concentration of the serial sub-culture that showed no visible growth. Apart from I. clemensiae, I. andersonii and Pseudomerulius curtisii were also able to show good inhibitory and bactericidal effects against both $S$. aureus and P. acnes. P. stiptica was the only sample that had detectable MIC and MBC values specifically for $P$. acnes. The positive control for $S$. aureus, sorbic acid, showed an MIC value of $350 \mu \mathrm{g} / \mathrm{mL}$, which was higher than most of the samples tested. However, the positive control for $P$. acnes, benzalkonium chloride, required only 10 and $20 \mu \mathrm{g} / \mathrm{mL}$ to achieve the MIC and MBC values, respectively.

\section{Partial chemical characterization by LC-MS analysis}

LC-MS analysis was performed to elucidate the compounds present in the samples exhibiting detectable MIC and MBC. The retention time and the $\mathrm{m} / \mathrm{z}$, values of the molecular ion and the main fragments are shown in Table 3. The LC chromatograms are provided as online resource in Fig. S1 (a-1). Tentative identification of some of the compounds present in the extracts was done on the basis of the $\mathrm{m} / \mathrm{z}$ values of the molecular ions and the major fragments. The major compound that was common to $I$. andersonii, I. clemensiae, and I. cuticularis showed molecular ion peaks with $\mathrm{m} / \mathrm{z}$ values of 247.0467, 247.0437, and 247.0442 in positive mode and 245.0497, 245.0303 , and 245.0334 in negative mode, respectively. The latter two species also showed an $[2 \mathrm{M}-\mathrm{H}]^{-}$ion of 491.0730 and 491.0694 , respectively. The compound was speculated to be hispidin (exact mass $246.0528 \mathrm{~g} / \mathrm{mol}$ ). Furthermore, the retention time and ultraviolet-visible (UV-Vis) spectrum were compared with the commercially available standard compound too. However, its presence was not seen in Inonotus sp. 2. The biosynthesis of hispidin analogs in Inonotus obliquus is known to be regulated by exposure to light and presence of fungal elicitors [19]. These factors could be the reason for its absence in Inonotus sp. 2.

Cyclomyces setiporus 3 showed the presence of compounds with molecular ion peaks having $\mathrm{m} / \mathrm{z}$ values of $182.9373,139.0481,155.0094$, and 153.0496, respectively, in positive mode; and 181.0792, 137.0034, 153.0040, and 151.1258 , respectively, in negative mode. Therefore, the presence of homovanillic acid (exact mass $182.1733 \mathrm{~g} / \mathrm{mol}$ ), protocatechualdehyde (exact mass $138.1207 \mathrm{~g} / \mathrm{mol}$ ), protocatechuic acid (exact mass $154.1201 \mathrm{~g} / \mathrm{mol}$ ), and vanillin (exact mass $152.0473 \mathrm{~g} / \mathrm{mol}$ ) were predicted. Further comparisons with the respective standard compounds were also done. Although the molecular ion peaks and some main fragments could be determined, the complete identity of the compounds remained elusive for $P$. stiptica, M. mucida, Gymnopus sp., Xylobolus princeps 2 and 3, Pseudomerulius curtisii, and C. ferruginascens. 
Table 2 Minimum inhibitory concentration (MIC) and minimum bactericidal concentration $(\mathrm{MBC})$ of the ethanol extracts exhibiting the highest inhibition percentage

\begin{tabular}{|c|c|c|c|c|}
\hline \multirow[t]{2}{*}{ Scientific name } & \multicolumn{2}{|l|}{ S. aureus } & \multicolumn{2}{|l|}{ P. acnes } \\
\hline & MIC $(\mu \mathrm{g} / \mathrm{mL})$ & $\mathrm{MBC}(\mu \mathrm{g} / \mathrm{mL})$ & $\mathrm{MIC}(\mu \mathrm{g} / \mathrm{mL})$ & $\mathrm{MBC}(\mu \mathrm{g} / \mathrm{mL})$ \\
\hline Inonotus andersonii & 200 & 200 & 200 & 200 \\
\hline Inonotus clemensiae & 100 & 100 & 100 & 200 \\
\hline Inonotus cuticularis & 200 & 200 & - & - \\
\hline Inonotus sp. 2 & 400 & nd & - & - \\
\hline Cyclomyces setiporus 3 & 400 & nd & - & - \\
\hline Postia stiptica & - & - & 100 & 200 \\
\hline Mucidula mucida. & 250 & 400 & - & - \\
\hline Gymnopus sp. & 200 & nd & - & - \\
\hline Xylobolus princeps 2 & 200 & nd & - & - \\
\hline Xylobolus princeps 3 & 400 & nd & - & - \\
\hline Pseudomerulius curtisii & 100 & 200 & 200 & 400 \\
\hline Cantharellus ferruginascens & 100 & 400 & - & - \\
\hline Sorbic acid & 350 & nd & - & - \\
\hline Benzalkonium chloride & - & - & 10 & 20 \\
\hline
\end{tabular}

S. aureus, Staphylococcus aureus; P. acnes, Propionibacterium acnes; MIC, minimum inhibitory concentration; MBC, minimum bactericidal concentration; nd, MBC was not detected; -, MIC and MBC were not investigated for the particular bacterial species

\section{NMR analysis}

The structure of the major compounds present in $I$. clemensiae and $C$. setiporus were confirmed to be hispidin and protocatechualdehyde, respectively, with the help of ${ }^{1} \mathrm{H}$ and ${ }^{13} \mathrm{C}$ NMR analyses, followed by heteronuclear multiple bond correlation (HMBC) and heteronuclear single quantum correlation (HSQC) experiments; and also by comparison to previously reported spectral data for hispidin $[20,21]$ and protocatechualdehyde $[22,23]$. The details of the NMR analysis are provided as supplementary information SI 1, SI 2, Table S1, and Table S2.

\section{MIC and MBC of pure compounds}

The compounds identified in the bioactive extracts, were checked again for the MIC and MBC values, to confirm the source of antibacterial activity in the extracts. Table 4 shows the MIC and MBC exhibited by the pure compounds. Also, the structure of the compounds investigated for MIC and MBC values are shown in Fig. 1. Hispidin showed an MIC and MBC value of $25 \mu \mathrm{g} / \mathrm{mL}$ for $S$. aureus; and an MIC and MBC value of $100 \mu \mathrm{g} / \mathrm{mL}$ for $P$. acnes. However, the extracts of $I$. andersonii and $I$. clemensiae exhibited the same MIC value for both bacterial species. This could be due to the presence of some minor compounds in the extracts which enhanced the antibacterial effect towards $P$. acnes. Protocatechualdehyde exhibited an MIC value of $400 \mu \mathrm{g} / \mathrm{mL}$ for $S$. aureus and the MBC was not detected up to the maximum tested concentration of
$400 \mu \mathrm{g} / \mathrm{mL}$. Also, the MIC and MBC could not be detected for other compounds in $C$. setiporus such as homovanillic acid, protocatechuic acid, and vanillin at the maximum tested concentration of $400 \mu \mathrm{g} / \mathrm{mL}$.

\section{Discussion}

The bacterial species $S$. aureus and P. acnes are known to be opportunistic pathogens capable of causing severe infections [24, 25]. Ethanol extracts of various wild mushrooms of Nepal, especially those belonging to the group Hymenochaetales, showed promising antibacterial activity. The MIC and MBC values could be detected against both $S$. aureus and $P$. acnes for the extracts of $I$. clemensiae, I. andersonii from Hymenochaetales and Pseudomerulius curtisii from the Others group. Very few studies could be found on the antibacterial activity of mushroom extracts on $P$. acnes [26]. Therefore, the present study shall be an important addition in this field.

Phenolic compounds are an important group of compounds responsible for the antibacterial activity of mushrooms [27]. Previous investigations of the total phenolic content of the ethanol extracts of Nepalese wild mushrooms $[13,14]$ showed very high phenolic content in $I$. clemensiae, I. andersonii, I. cuticularis, C. setiporus and Pseudomerulius curtisii. However, the very low phenolic content in P. stiptica, M. mucida, Gymnopus sp. and $C$. ferruginascens indicates the presence of other equally potent antibacterial compounds. The oily nature of the 
Table 3 Retention time (Rt) and $m / z$ values of the liquid chromatography-mass spectrometry (LC-MS) detectable compounds in the ethanol extracts of mushrooms showing Minimum inhibitory concentration (MIC) and minimum bactericidal concentration (MBC) values against Staphylococcus aureus and/or Propionibacterium acnes

\begin{tabular}{|c|c|c|c|c|c|c|}
\hline Scientific name & $\begin{array}{l}\mathrm{Rt} \\
(\mathrm{min})\end{array}$ & {$[\mathrm{M}+\mathrm{H}]^{+}$} & Main fragments & {$[\mathrm{M}-\mathrm{H}]^{-}$} & Main fragments & Identified compounds \\
\hline Inonotus andersonii & 12.59 & 247.0467 & & 245.0497 & & Hispidin (std) \\
\hline $\begin{array}{l}\text { Inonotus } \\
\text { clemensiae }\end{array}$ & 12.70 & 247.0437 & & 245.0303 & $491.0730(2 \mathrm{M}-\mathrm{H})^{-}$ & Hispidin (NMR) \\
\hline \multirow[t]{2}{*}{ Inonotus cuticularis } & 11.97 & 330.0516 & $313.1009,285.0553$ & 328.1289 & & NI \\
\hline & 12.61 & 247.0442 & $\begin{array}{l}229.6337,212.5372 \\
163.0358\end{array}$ & 245.0334 & $491.0694(2 \mathrm{M}-\mathrm{H})^{-}$ & Hispidin (std) \\
\hline Inonotus sp. 2 & 28.80 & 189.0609 & & & & $\mathrm{NI}$ \\
\hline \multirow[t]{4}{*}{$\begin{array}{l}\text { Cyclomyces } \\
\text { setiporus } 3\end{array}$} & 6.63 & 182.9373 & & 181.0792 & & $\begin{array}{l}\text { Homovanillic acid } \\
\text { (std) }\end{array}$ \\
\hline & 8.07 & 139.0481 & & 137.0034 & & $\begin{array}{l}\text { Protocatechualdehyde } \\
\text { (NMR) }\end{array}$ \\
\hline & 9.28 & 155.0094 & & 153.0040 & & $\begin{array}{l}\text { Protocatechuic acid } \\
\text { (std) }\end{array}$ \\
\hline & 10.98 & 153.0496 & & 151.1258 & & Vanillin (std) \\
\hline \multirow[t]{4}{*}{ Postia stiptica } & 14.01 & 277.2020 & $253.1551,239.1103$ & 275.3043 & & NI \\
\hline & 48.41 & & & 631.3535 & 483.3416 & NI \\
\hline & 49.80 & & & 629.3742 & & $\mathrm{NI}$ \\
\hline & 71.46 & 453.3076 & $435.3409,284.2561$ & 451.3297 & & NI \\
\hline \multirow[t]{2}{*}{ Mucidula mucida } & 55.75 & & & 459.2670 & $413.2928,279.2006$ & NI \\
\hline & 68.71 & 415.3021 & $\begin{array}{r}394.2878,384.2462 \\
357.3313,339.2486\end{array}$ & 413.3745 & $\begin{array}{c}392.3676,347.2119 \\
325.2103,299.2541\end{array}$ & $\mathrm{NI}$ \\
\hline \multirow[t]{2}{*}{ Gymnopus sp. } & 53.93 & 295.2167 & 277.2201 & 293.1744 & & NI \\
\hline & 55.363 & 295.2121 & & 293.2052 & & $\mathrm{NI}$ \\
\hline $\begin{array}{l}\text { Xylobolus princeps } \\
2\end{array}$ & 19.30 & 318.2628 & 289.0561 & & & NI \\
\hline \multirow{2}{*}{$\begin{array}{l}\text { Xylobolus princeps } \\
3\end{array}$} & 22.77 & 235.0845 & 191.0667 & & & $\mathrm{NI}$ \\
\hline & 28.51 & 189.0691 & & & & NI \\
\hline \multirow{5}{*}{$\begin{array}{l}\text { Pseudomerulius } \\
\text { curtisii }\end{array}$} & 12.92 & & & 497.1496 & & NI \\
\hline & 13.98 & & & 453.0995 & $429.2301,324.0877$ & NI \\
\hline & 15.91 & 411.0475 & $363.2784,266.0553$ & 409.0760 & 323.0709 & $\mathrm{NI}$ \\
\hline & 21.32 & 545.1939 & & 543.1415 & & $\mathrm{NI}$ \\
\hline & 46.66 & 591.1802 & & 589.1289 & 531.2800 & $\mathrm{NI}$ \\
\hline \multirow{4}{*}{$\begin{array}{l}\text { Cantharellus } \\
\text { ferruginascens }\end{array}$} & 45.86 & 275.1962 & $198.1015,177.6052$ & 273.1675 & & $\mathrm{NI}$ \\
\hline & 52.20 & 291.1368 & 273.1826 & 289.1754 & & NI \\
\hline & 53.33 & 295.2618 & 277.1925 & 293.1787 & & NI \\
\hline & 54.26 & 295.2367 & 277.2015 & 293.1874 & & NI \\
\hline
\end{tabular}

NI means not identified, standard (std) means that the identity of the compounds were confirmed by comparing with the retention time and ultraviolet-visible (UV-Vis) spectra of standard compounds, and nuclear magnetic resonance (NMR) means that the compounds were confirmed by proton $\left({ }^{1} \mathrm{H}\right)$ and carbon-13 $\left({ }^{13} \mathrm{C}\right)$ NMR analysis, followed by heteronuclear multiple bond correlation (HMBC) and heteronuclear single quantum correlation (HSQC) experiments

ethanolic extracts of M. mucida and C. ferruginascens indicate the presence of unsaturated fatty acids. Unsaturated fatty acids with a length of more than 14 carbons, bearing specific functional groups are known to have strong bactericidal effect [28]. Mucidula mucida is better known for the presence of antifungal compounds such as strobilurins and oudemansins [29]. A class of compounds known as $p$-terphenyls exhibiting antifungal and antibacterial activities has been isolated from Pseudomerulius curtisii [30, 31]. Kozarski et al. [32] have attributed several bioactive properties, including antibacterial activity of the methanolic extract of Cantharellus cibarius to the phenolic content. However, C. ferruginascens used in this study had very low phenolic content [14]. Although reports about the 
Table 4 Minimum inhibitory concentration (MIC) and minimum bactericidal concentration (MBC) of the samples exhibiting highest inhibition percentage

\begin{tabular}{lcclll}
\hline Compound & \multicolumn{2}{l}{ S. aureus } & & \multicolumn{2}{l}{ P. acnes } \\
\cline { 2 - 3 } & MIC $(\mu \mathrm{g} / \mathrm{mL})$ & MBC $(\mu \mathrm{g} / \mathrm{mL})$ & & MIC $(\mu \mathrm{g} / \mathrm{mL})$ & MBC $(\mu \mathrm{g} / \mathrm{mL})$ \\
\hline (1) Hispidin & 25 & 25 & 100 & 100 \\
(2) Homovanillic acid & $>400$ & $>400$ & - & - \\
(3) Protocatechualdehyde & 400 & $>400$ & - & - \\
(4) Protocatechuic acid & $>400$ & $>400$ & - & - \\
(5) Vanillin & $>400$ & $>400$ & - & - \\
\hline
\end{tabular}

S. aureus, Staphylococcus aureus; P. acnes, Propionibacterium acnes; -, means that the MIC and MBC values were not investigated for the respective compounds<smiles>O=c1cc(O)cc(/C=C/c2ccc(O)c(O)c2)o1</smiles>

1. Hispidin<smiles>[R7]Oc1cc([R2])c([R3])cc1O</smiles>

2. Homovanillic acid $\left(\mathrm{R}_{1}=\mathrm{CH}_{3}, \mathrm{R}_{2}=\mathrm{CH}_{2} \mathrm{COOH}, \mathrm{R}_{3}=\mathrm{H}\right)$

3. Protocatechualdehyde $\left(\mathrm{R}_{1}=\mathrm{H}, \mathrm{R}_{2}=\mathrm{CHO}, \mathrm{R}_{3}=\mathrm{H}\right)$

4. Protocatechuic acid $\left(\mathrm{R}_{1}=\mathrm{H}, \mathrm{R}_{2}=\mathrm{COOH}, \mathrm{R}_{3}=\mathrm{H}\right)$

5. Vanillin $\left(\mathrm{R}_{1}=\mathrm{CH}_{3}, \mathrm{R}_{2}=\mathrm{CHO}, \mathrm{R}_{3}=\mathrm{H}\right)$

Fig. 1 Chemical structures of compounds 1-5

extensive chemical characterization of $P$. stiptica could not be found, the cultured mycelia are known to produce organic acids such as oxalic acid [33]. The bioactive compounds of natural products, including mushrooms, are known to be influenced by several factors including growth stage [34], season, and abiotic stress [35], to name a few. The variations can be observed within population groups of the same species too, as demonstrated by Cirak et al. [36]. In their study, the chemical diversity in the Hypericum populations was attributed to changes in geographic locations, and the phenotypic plasticity of the plant to the varying environmental conditions.

Hispidin, the major phenolic compound in both $I$. clemensiae and I. andersonii, was capable of imparting very strong antibacterial activity to the mushrooms. It is a styrylpyrone class compound renowned for its antioxidant properties [37], anti-inflammatory and anticancer properties [38]. Protocatechualdehyde in C. setiporus was also capable of contributing for moderate activity against $S$. aureus. This compound has also been reported from other mushroom species such as Phellinus gilvus [39], which belongs to the same family as $C$. setiporus.

The present study reports the antibacterial activity of a large number of Nepalese mushrooms against $S$. aureus and $P$. acnes for the first time. Very few studies have reported the inhibitory activity of mushrooms against $P$. acnes. These findings pave the way for potential use of Nepalese mushrooms as functional ingredients, especially for skin health products. Further investigation of the mechanism of the antibacterial activity shall contribute for the expansion of their use in other therapeutic areas too.

Acknowledgements The authors would like to thank the Center for Advanced Instrumental and Educational Support, Faculty of Agriculture, Kyushu University for supporting the LCMS-IT-TOF analysis; and the Network Joint Research Center for Materials and Devices, Kyushu University for the NMR analysis. We are thankful to Nepal Agricultural Research Council for providing the mushroom samples. The support of the Ministry of Education, Culture, Sports, Science and Technology of Japan (MEXT) in the form of $\mathrm{PhD}$ Scholarship is greatly acknowledged. This work was supported by KAKENHI Grant Number 26304047.

\section{References}

1. Cogen AL, Nizet V, Gallo RL (2008) Skin microbiota: a source of disease or defence? Br J Dermatol 158:442-455

2. Otto M (2010) Staphylococcus colonization of the skin and antimicrobial peptides. Expert Rev Dermatol 5:183-195

3. Tripathi SV, Gustafson CJ, Huang KE, Feldman SR (2013) Side effects of common acne treatments. Expert Opin Drug Saf 12:39-51

4. Ribeiro A, Estanqueiro M, Oliveira M, Sousa Lobo J (2015) Main benefits and applicability of plant extracts in skin care products. Cosmetics 2:48-65

5. Lindequist U, Niedermeyer THJ, Jülich WD (2005) The pharmacological potential of mushrooms. Evid Based Compl Altern Med 2:285-299

6. Mizuno T (1995) Bioactive biomolecules of mushrooms: food function and medicinal effect of mushroom fungi. Food Rev Int 11:5-21

7. Sullivan R, Smith JE, Rowan NJ (2006) Medicinal mushrooms and cancer therapy: translating a traditional practice into Western medicine. Perspect Biol Med 49:159-170 
8. Taofiq O, González-Paramás AM, Martins A, Barreiro MF, Ferreira ICFR (2016) Mushrooms extracts and compounds in cosmetics, cosmeceuticals and nutricosmetics-a review. Ind Crops Prod 90:38-48

9. Alves M, Ferreira IFR, Dias J, Teixeira V, Martins A, Pintado M (2012) A review on antimicrobial activity of mushroom (basidiomycetes) extracts and isolated compounds. Planta Med 78:1707-1718

10. Desbois AP, Lawlor KC (2013) Antibacterial activity of longchain polyunsaturated fatty acids against Propionibacterium acnes and Staphylococcus aureus. Mar Drugs 11:4544-4557

11. Adhikari MK (2012) Researches on the Nepalese mycoflora-2. KS Adhikari, Kathmandu, Nepal 20:1-84

12. Christensen M, Bhattarai S, Devkota S, Larsen HO (2008) Collection and use of wild edible fungi in Nepal. Econ Bot 62:12-23

13. Hai Bang T, Suhara H, Doi K, Ishikawa H, Fukami K, Parajuli GP, Katakura Y, Yamashita S, Watanabe K, Adhikari MK, Manadhar HK, Kondo R, Shimizu K (2014) Wild mushrooms in Nepal: some potential candidates as antioxidant and ACE-inhibition sources. Evid Based Compl Altern Med 2014:1-11

14. Tamrakar S, Tran HB, Nishida M, Kaifuchi S, Suhara H, Doi K, Fukami K, Parajuli GP, Shimizu K (2016) Antioxidative activities of 62 wild mushrooms from Nepal and the phenolic profile of some selected species. J Nat Med 70:769-779

15. Tanaka A, Zhu Q, Tan H, Horiba H, Ohnuki K, Mori Y, Yamauchi R, Ishikawa H, Iwamoto A, Kawahara H, Shimizu K (2014) Biological activities and phytochemical profiles of extracts from different parts of bamboo (Phyllostachys pubescens). Molecules 19:8238-8260

16. Quereshi S, Pandey AK, Sandhu SS (2010) Evaluation of antibacterial activity of different Ganoderma lucidum extracts. People's J Sci Res 3:9-14

17. Bala N, Aitken EA, Fechner N, Cusack A, Steadman KJ (2011) Evaluation of antibacterial activity of Australian basidiomycetous macrofungi using a high-throughput 96-well plate assay. Pharm Biol 49:492-500

18. Glamočlija J, Ćirić A, Nikolić M, Fernandes Â, Barros L, Calhelha RC, Ferreira ICFR, Soković M, Griensven LJLDV (2015) Chemical characterization and biological activity of Chaga (Inonotus obliquus), a medicinal "mushroom". J Ethnopharmacol 162:232-332

19. Zheng W, Miao K, Liu Y, Zhao Y, Zhang M, Pan S, Dai Y (2010) Chemical diversity of biologically active metabolites in the sclerotia of Inonotus obliquus and submerged culture strategies for up-regulating their production. Appl Microbiol Biotechnol 87:1237-1254

20. Jung JY, Lee IK, Seok SJ, Lee HJ, Kim YH, Yun BS (2008) Antioxidant polyphenols from the mycelial culture of the medicinal fungi Inonotus xeranticus and Phellinus linteus. J Appl Microbiol 104:1824-1832

21. Park IH, Chung SK, Lee KB, Yoo YC, Kim SK, Kim GS, Song KS (2004) An antioxidant hispidin from the mycelial cultures of Phellinus linteus. Arch Pharm Res 27:615-618

22. Ayinde BA, Onwukaeme DN, Omogbai EK (2007) Isolation and characterization of two phenolic compounds from the stem bark of Musanga cecropioides R. Brown (Moraceae). Acta Pol Pharm Drug Res 64:183-185

23. Alvarenga TA, Bêdo TRFO, Braguine CG, Gonçalves UO, Magalhães LG, Rodrigues V, Gimenez VMM, Groppo M, Silva MLA, Cunha WR, Januário AH, Pauletti PM (2012) Evaluation of Cuspidaria pulchra and its isolated compounds against Schistosoma mansoni Adult Worms. Int J Biotechnol Wellness Ind 1:121-127

24. Achermann Y, Goldstein EJC, Coenye T, Shirtliffa ME (2014) Propionibacterium acnes: from commensal to opportunistic biofilm-associated implant pathogen. Clin Microbiol Rev 27:419-440

25. Coates R, Moran J, Horsburgh MJ (2014) Staphylococci: colonizers and pathogens of human skin. Future Microbiol 9:75-91

26. Fan L, Pan H, Soccol AT, Pandey A, Soccol CR (2006) Advances in mushroom research in the last decade. Food Technol Biotechnol 44:303-311

27. Alves MJ, Ferreira ICFR, Froufe HJC, Abreu RM, Martins A, Pintado M (2013) Antimicrobial activity of phenolic compounds identified in wild mushrooms, SAR analysis and docking studies. J Appl Microbiol 115:346-357

28. Cartron ML, England SR, Chiriac AI, Josten M, Turner R, Rauter Y, Hurd A, Sahl HG, Jones S, Foster SJ (2014) Bactericidal activity of the human skin fatty acid cis-6-hexadecanoic acid on Staphylococcus aureus. Antimicrob Agents Chemother 58:3599-3609

29. Gurwitz JH, Avorn J (1989) Antibiotics from basidiomycetes. IX. Oudemansin, an antifungal antibiotic from Oudemansiella mucida (Schrader ex Fr.) Hoehnel (Agaricales). Supplements 29:13-25

30. In-Kyoung L, Ki DW, Kim SE (2013) $p$ - Terphenyls from fungus Paxillus curtisii chelate irons: a proposed role of $p$-terphenyls in fungus. J Microbiol Biotechnol 23:652-655

31. Liu JK (2006) Natural terphenyls: developments since 1877. Chem Rev 106:2209-2223

32. Kozarski M, Klaus A, Vunduk J, Zizak Z, Niksic M, Jakovljevic D, Vrvic MM, Van Griensven LJ (2015) Nutraceutical properties of the methanolic extract of edible mushroom Cantharellus cibarius (Fries): primary mechanisms. Food Funct 6:1875-1886

33. Liaud N, Giniés C, Navarro D, Fabre N, Crapart S, Gimbert IH, Levasseur A, Raouche S, Sigoillot JC (2014) Exploring fungal biodiversity: organic acid production by 66 strains of filamentous fungi. Fungal Biol Biotechnol 1:10

34. Barros L, Baptista P, Estevinho LM, Ferreira ICFR (2007) Effect of fruiting body maturity stage on chemical composition and antimicrobial activity of Lactarius sp. mushrooms. J Agric Food Chem 55:8766-8771

35. Sudheer S, Yeoh WK, Manickam S, Ali A (2016) Effect of ozone gas as an elicitor to enhance the bioactive compounds in Ganoderma lucidum. Postharvest Biol Technol 117:81-88

36. Cirak C, Radusiene J, Ivanauskas L, Jakstas V, Çamaş N (2014) Changes in the content of bioactive substances among Hypericum montbretii populations from Turkey. Braz J Pharmacogn $24: 20-24$

37. Lee IK, Han MS, Lee MS, Kim YS, Yun BS (2010) Styrylpyrones from the medicinal fungus Phellinus baumii and their antioxidant properties. Bioorganic Med Chem Lett 20:5459-5461

38. Ferreira ICFR, Vaz JA, Vasconcelos MH, Martins A (2010) Compounds from wild mushrooms with antitumor potential. Anticancer Agents Med Chem 10:424-436

39. Chang Z-Q, Gebru E, Lee SP, Rhee MH, Kim JC, Cheng H, Park SC (2011) In vitro antioxidant and anti-inflammatory activities of protocatechualdehyde isolated from Phellinus gilvus. J Nutr Sci Vitaminol (Tokyo) 57:118-122 